\title{
Association between polymorphisms in long non-coding RNA PRNCR1 in 8q24 and risk of colorectal cancer
}

\author{
Lijuan $\mathrm{Li}^{1,2 \dagger}$, Ruifen Sun ${ }^{3 \dagger}$, Yundan Liang ${ }^{1,2}$, Xinmin Pan ${ }^{2,4}$, Zhaohui $\mathrm{Li}^{5}$, Peng Bai ${ }^{2}$, Xiaofeng Zeng ${ }^{6}$, \\ Dongxian Zhang ${ }^{6}$, Lin Zhang ${ }^{1,2^{*}}$ and Linbo Gao ${ }^{1 *}$
}

\begin{abstract}
Background: Genome-wide association studies have identified that genetic variants in 8q24 confer susceptibility to colorectal cancer (CRC). Recently, a novel IncRNA (PRNCR1) that located in the 8q24 was discovered. Single nucleotide polymorphisms (SNPs) in the IncRNAs may influence the process of splicing and stability of mRNA conformation, resulting in the modification of its interacting partners. We hypothesized that SNPs in the IncRNA PRNCR1 may be related to the risk of CRC.
\end{abstract}

Methods: We conducted a case-control study and genotyped five tag SNPs in the IncRNA PRNCR1 in 908 subjects including 313 cases with CRC and 595 control subjects using polymerase chain reaction-restriction fragment length polymorphism (PCR-RFLP) assay.

Results: In overall analyses, we found that the rs13252298 and rs1456315 were associated with significantly decreased risks of CRC. In stratification analyses, we found that CRC patients carrying the rs $1456315 \mathrm{G}$ were likely to have a tumor size of greater than $5 \mathrm{~cm}$ (G vs. A: adjusted $\mathrm{OR}=1.56,95 \% \mathrm{Cl}: 1.10-2.23$ ). Additionally, patients with the rs7007694C and rs16901946G had decreased risks to develop poorly differentiated CRC, whereas patients with the rs1456315G had an increased risk to develop poorly differentiated CRC.

Conclusion: These findings suggest that SNPs in the InCRNA PRNCR1 may contribute to susceptibility to CRC.

Keywords: Colorectal cancer, LncRNAs, Polymorphism

\section{Introduction}

Cancer including colorectal cancer (CRC) is a disease accumulated with multistep genetic and epigenetic level changes and with a complex etiology [1]. Genome-wide association scans and subsequent observational replication studies have identified that genetic variants located at the chromosomal region 8q24 confer susceptibility to CRC [2-17]. However, the region was called "genedesert" area because it does not harbor any candidate

\footnotetext{
*Correspondence: zhanglin@scu.edu.cn; cdchglb@gmail.com

${ }^{+}$Equal contributors

${ }^{1}$ Laboratory of Molecular and Translational Medicine, West China Institute of Women and Children's Health; Key Laboratory of Obstetric \& Gynecologic and Pediatric Diseases and Birth Defects of Ministry of Education, West China Second University Hospital, Sichuan University, Chengdu, Sichuan 610041, P.R. China

${ }^{2}$ Department of Forensic Biology, West China School of Preclinical and Forensic Medicine, Sichuan University, Chengdu, Sichuan 610041, P.R. China Full list of author information is available at the end of the article
}

gene except for the putative gene POU5F1P1 whose function is unknown [18], causing the function of the variations in the susceptibility loci is not well established.

Recently, a $\sim 13$ kb long non-coding RNAs (lncRNA) was discovered that was transcribed from the "genedesert" region of chromosome 8q24 (128.14-128.28 Mb) [19]. The IncRNA, termed prostate cancer non-coding RNA 1 (PRNCR1), was reported to be involved in the carcinogenesis of prostate cancer [19]. Therefore, further characterization of lncRNA related single nucleotide polymorphisms (SNPs) may open a new avenue for functional analysis of cancer susceptibility loci identified by genomewide association study, especially when it was located in introns or "gene-desert" region.

LncRNAs are RNA polymerase II-transcribed, polyadenylated, and frequently alternatively spliced RNAs $[20,21]$ with the features of cell-type specific expression 
patterns [22-24], distinct subcellular localizations [24], linkage to various diseases [25], and evolutionary selection of the lncRNA sequence [26,27]. LncRNAs can be intergenic, intronic, antisense or overlapping with proteincoding genes or other ncRNAs [26,28-30]. Recent studies have revealed the contribution of ncRNAs as protooncogene [31], tumor suppressor gene [32], drivers of metastasis transformation in cancer development [33]. The expression of lncRNAs is deregulated in different cancers, including colon cancer [34]. Several lines of evidence have shown that SNPs in lncRNAs may influence the process of splicing and stability of mRNA conformation, resulting in the modification of its interacting partners [19,35].

In this study, we hypothesized that SNPs in lncRNAs may be involved in the risk of CRC. To test this hypothesis, we selected five tag SNPs in the IncRNA PRNCR1 in the "gene-desert" region of 8q24 (i.e., rs1016343, rs13252298, rs7007694, rs16901946, and rs1456315), and genotyped the SNPs in a case-control study of 313 cases with CRC and 595 ethnicity-matched controls in a Chinese population.

\section{Subjects and methods Subjects}

Totally, 908 subjects attended our case-control study comprising 313 cases (313 patients with CRC including 199 males and 114 females) and 595 control subjects (289 males and 306 females). Diagnosis of CRC was confirmed by histopathological examination and those who had inflammatory bowel disease were excluded. Patients were recruited from the Luoyang Central Hospital and the West China Hospital, Sichuan University between January 2010 and February 2012. Control subjects including 595 healthy volunteers who came to the West China Hospital just for routine check-up during the same time as the patients. Individuals were excluded if there was any evidence of personal or family history of cancer or inflammatory diseases in the intestine, such as ulcerative colitis or Crohn's colitis. There was no significant difference between patients and control subjects in terms of ethnicity distribution. Written informed consent was obtained from all subjects attending this study, and the study was performed with the approval of the ethics committee of the hospital.

\section{Selection of SNPs}

We searched tag SNPs in the IncRNAs PRNCR1 in the chromosomal region 8q24 using UCSC (http://genome. ucsc.edu/) with the selection criteria of the minor allele frequency more than 0.10 in Asians. Finally, five tag SNPs were identified: rs1016343 (Chr8-128162479), rs13252298 (Chr8-128164338), rs7007694 (Chr8-128168348), rs16901946 (Chr8- 128170107), and rs1456315 (Chr8-128173119).

\section{Genotyping}

$2 \mathrm{~mL}$ peripheral blood used for genotyping assay was obtained from each subject after their admission to the hospital, and each subject was interviewed to obtain demographic and clinical information. Genomic DNA was extracted from the blood of the subjects using a commercial extraction kit (Bioteke Corporation, Beijing, China) according to the manufacturer's directions. We used a polymerase chain reaction-restriction fragment length polymorphism (PCR-RFLP) assay to acquire all the genotypes of the five SNPs (i.e., rs1016343, rs13252298, rs7007694, rs16901946, and rs1456315). Primer sequences, reaction conditions, restriction enzymes (New England BioLabs Inc; Beverly, MA, USA.) and length of polymerase chain reaction products are summarized in Additional file 1: Table S1. Restriction fragments were distinguished on $6 \%$ polyacrylamide gels and visualized by silver staining to identify the genotypes. For quality control, the PCR products of the five SNPs with different genotypes were confirmed by DNA sequencing, and the results were 100\% concordant. Additionally, $10 \%$ of the whole samples were repeated, and positive and negative controls were used in each 96-well PCR plate.

\section{Statistical analysis}

Allele and genotype frequencies of the five SNPs were obtained using Modified-Powerstates standard edition software. Hardy-Weinberg equilibrium was tested with a goodness of fit chi-square test (with one degree of freedom) to compare the observed genotype frequencies among the subjects with the expected genotype frequencies. The demographic and clinical data of the two groups were compared using the chi-square test. Bivariate logistic regression was used to calculate the odds ratios (ORs), 95\% confidence intervals (CIs), and corresponding $p$ values after adjustment for age and gender. $P<0.05$ is considered statistically significant. All data were analyzed using the SPSS for Windows software package version 13.0 (SPSS Inc., Chicago. IL).

\section{Results}

The five SNPs of rs1016343, rs13252298, rs7007694, rs16901946, and rs1456315 in 8q24 were successfully genotyped for 908 subjects. The clinical features of subjects enrolled in our study are shown in Table 1. The genotype frequencies of the five polymorphisms in the control group met the requirements of the HardyWeinberg equilibrium $(P>0.05)$. The genotype and allele frequencies of the five SNPs are summarized in Table 2. The AG genotype and G allele of rs13252298 were associated with a significantly decreased risk of CRC, compared with the AA genotype and A allele (AG vs. AA, adjusted $\mathrm{OR}=0.67,95 \%$ CI: 0.49-0.91, $p=0.01$; G vs. A, adjusted $\mathrm{OR}=0.75,95 \%$ CI: 0.60-0.94, $p=0.01$, respectively). 
Table 1 Demographics of patients with CRC and controls

\begin{tabular}{lll}
\hline Variables & Controls $\mathbf{n}=\mathbf{5 9 5}$ (\%) & CRC $\mathbf{n}=\mathbf{3 1 3} \mathbf{( \% )}$ \\
\hline Mean age (y) & $51.5( \pm 10.9)$ & $59.8( \pm 13.8)$ \\
Gender & \\
Male & 289(48.6) & $199(63.6)$ \\
Female & 306(51.4) & \\
Tumor size & & $114(36.4)$ \\
$<5$ cm & & $174(55.6)$ \\
$\geq 5$ cm & \\
Differentiated status & & $242(77.3)$ \\
Well-Moderately & & $71(22.7)$ \\
Poorly-Undifferentiated & \\
Clinical stage & $168(53.7)$ \\
I-II & $145(46.3)$ \\
III- IV & \\
Metastasis & \\
Yes & $141(45.0)$ \\
No & $172(55.0)$ \\
\hline
\end{tabular}

Moreover, the AG genotype of rs1456315 was also associated with a significantly decreased risk of CRC, compared with the AA genotype (AG vs. AA, adjusted $\mathrm{OR}=0.66$, $95 \%$ CI: 0.48-0.90, $p=0.01)$. However, no significant association was observed between the other SNPs and risk of CRC. Besides, we examined the linkage disequilibrium (LD) plot,and the 5 SNPs was not in LD (data not shown).

When patients were divided according to tumor size, differentiated status, clinical stage, and metastasis status, we found that CRC patients carrying the rs1456315G allele were likely to have a tumor size of greater than $5 \mathrm{~cm}$ (G vs. A: adjusted OR=1.56, 95\% CI: $1.10-2.23$ ). Additionally, patients with the rs7007694C allele and rs16901946G allele had a decreased risk to develop poorly differentiated CRC (rs7007694 C vs. T: adjusted $\mathrm{OR}=0.46,95 \% \mathrm{CI}: 0.28-0.77$; rs $16901946 \mathrm{G}$ vs. A: adjusted OR $=0.59,95 \%$ CI: 0.37-0.94, respectively). Interestingly, patients with the rs1456315G allele had an increased risk to develop poorly differentiated CRC (adjusted OR $=1.54,95 \%$ CI: 1.03-2.31) (Table 3).

\section{Discussion}

In the present study, for the first time, we provided evidence that SNPs (i.e., rs13252298, rs7007694, rs16901946, and rs1456315) in the IncRNA PRNCR1 at the "genedesert" region in 8q24 might be associated with CRC susceptibility. We identified the rs13252298 and rs1456315 were associated with significantly decreased risks of CRC. In stratification analyses, we found that the rs 1456315 was related to the tumor size of CRC. Moreover, patients with the rs7007694C allele and rs16901946G allele had decreased risks to develop poorly differentiated CRC,
Table 2 Genotype and allele frequencies of the five SNPs between cases and controls

\begin{tabular}{|c|c|c|c|c|}
\hline Polymorphisms & $\begin{array}{l}\text { Controls } \\
(n=595)(\%)\end{array}$ & $\begin{array}{l}\text { CRC }(n=313) \\
(\%)\end{array}$ & $\begin{array}{l}\text { Adjusted } \\
\text { OR }(95 \% \mathrm{Cl}) \\
\end{array}$ & $p$ \\
\hline \multicolumn{5}{|l|}{ rs1016343 } \\
\hline CC & 227(38.1) & 117(37.4) & 1.0(ref) & \\
\hline$C T$ & $276(46.4)$ & 156(49.8) & $1.33(0.82-2.14)$ & 0.25 \\
\hline$\pi$ & $92(15.5)$ & $40(12.8)$ & $1.13(0.83-1.55)$ & 0.44 \\
\hline C & $730(61.3)$ & $390(62.3)$ & 1.0(ref) & \\
\hline T & $460(38.7)$ & $236(37.7)$ & $1.14(0.92-1.41)$ & 0.24 \\
\hline \multicolumn{5}{|l|}{ rs13252298 } \\
\hline AA & $264(44.4)$ & 166(53.0) & 1.0 (ref) & \\
\hline$A G$ & $270(45.4)$ & 121(38.7) & $0.67(0.49-0.91)$ & 0.01 \\
\hline GG & $61(10.2)$ & $26(8.3)$ & $0.64(0.38-1.09)$ & 0.10 \\
\hline A & 798(67.1) & $453(72.4)$ & 1.0 (ref) & \\
\hline G & $392(32.9)$ & 173(27.6) & $0.75(0.60-0.94)$ & 0.01 \\
\hline \multicolumn{5}{|l|}{ rs7007694 } \\
\hline$\pi$ & $362(60.8)$ & 184(58.8) & 1.0(ref) & \\
\hline$C T$ & 208(35.0) & 107(34.2) & $1.04(0.76-1.42)$ & 0.80 \\
\hline CC & $25(4.2)$ & $22(7.0)$ & $1.60(0.85-3.03)$ & 0.15 \\
\hline T & $932(78.3)$ & $475(75.9)$ & $1.0($ ref) & \\
\hline C & $258(21.7)$ & $151(24.1)$ & $1.15(0.90-1.46)$ & 0.27 \\
\hline \multicolumn{5}{|l|}{ rs16901946 } \\
\hline AA & $338(56.8)$ & 175(55.9) & 1.0 (ref) & \\
\hline$A G$ & 232(39.0) & 117(37.4) & $0.96(0.71-1.31)$ & 0.80 \\
\hline $\mathrm{AG} / \mathrm{GG}$ & $257(43.2)$ & 138(44.1) & $1.03(0.77-1.38)$ & 0.85 \\
\hline A & $908(76.3)$ & $467(74.6)$ & 1.0 (ref) & \\
\hline G & $282(23.7)$ & 159(25.4) & $1.10(0.86-1.39)$ & 0.45 \\
\hline \multicolumn{5}{|l|}{ rs1456315 } \\
\hline AA & 294(49.4) & 167(53.4) & 1.0 (ref) & \\
\hline$A G$ & $262(44.0)$ & 119(38.0) & $0.66(0.48-0.90)$ & 0.01 \\
\hline GG & $39(6.6)$ & $27(8.6)$ & $1.09(0.62-1.91)$ & 0.78 \\
\hline A & $850(71.4)$ & $453(72.4)$ & 1.0 (ref) & \\
\hline G & $340(28.6)$ & 173(27.6) & $0.86(0.70-1.08)$ & 0.18 \\
\hline
\end{tabular}

OR: odds ratio; Cl: confidence interval; Ref: reference.

whereas patients with the rs1456315G allele had an increased risk to develop poorly differentiated CRC. These findings indicate that the polymorphisms in the lncRNA PRNCR1 may be related to the development of CRC, offering a novel and potential strategy for functional analysis of susceptibility loci to human diseases.

It has been shown that IncRNAs have developmental and tissue specific expression patterns, with an aberrant regulation in various diseases, including cancer [24,36-44]. LncRNAs have been reported to be involved in cancer development in three different ways: Firstly, some lncRNAs take part in the process as oncogene or oncogene regulator, for example, MALAT1 gene in non- 
Table 3 Stratified analyses of IncRNA PRNCR1 polymorphisms with clinical features in patients with CRC (minor allele vs. major allele)

\begin{tabular}{lllll}
\hline Polymorphisms & \multicolumn{4}{l}{ Adjusted OR for age and gender $(\mathbf{9 5 \%} \mathbf{C I}) / \boldsymbol{p}$} \\
\cline { 2 - 5 } & Tumor size $(\geq \mathbf{5} \mathbf{~ c m})$ & Differentiated status (poorly) & Clinical stage (III-IV) & Metastasis (yes) \\
\hline rs1016343C/T & $0.82(0.59-1.13) / 0.22$ & $1.05(0.72-1.55) / 0.79$ & $1.07(0.77-1.49) / 0.70$ & $1.27(0.91-1.78) / 0.16$ \\
rs13252298A/G & $1.07(0.75-1.52) / 0.72$ & $1.21(0.80-1.82) / 0.37$ & $0.85(0.59-1.21) / 0.36$ & $0.76(0.53-1.10) / 0.15$ \\
rs7007694T/C & $0.74(0.51-1.08) / 0.11$ & $0.46(0.28-0.77) / 0.003$ & $1.04(0.71-1.51) / 0.85$ & $1.11(0.76-1.62) / 0.59$ \\
rs16901946A/G & $0.84(0.59-1.22) / 0.36$ & $0.59(0.37-0.94) / 0.03$ & $1.09(0.76-1.58) / 0.64$ & $1.26(0.87-1.83) / 0.22$ \\
rs1456315A/G & $1.56(1.10-2.23) / 0.01$ & $1.54(1.03-2.31) / 0.04$ & $1.16(0.81-1.66) / 0.43$ & $1.06(0.73-1.52) / 0.77$ \\
\hline
\end{tabular}

CRC: colorectal cancer; OR: odds ratio; Cl: confidence interval.

The smaller size, well differentiated status, clinical stage I-II, and the ones without metastasis were made as references, respectively.

small cell lung cancer [45] and H19 in colon cancer [46]. The expression of MALAT1 was up-regulated in many kinds of human cancers such as breast cancer, prostate cancer, colon cancer, liver cancer, and uterus cancer [44,47-49]. Mice lacking $H 19$ presented an increased polyp count which is related to CRC [50]. Secondly, lncRNA may be related to cancer metastasis or prognosis. Gupta et al. reported a lncRNA HOTAIR which was associated with cancer metastasis and poor survival [33]. Thirdly, lncRNAs appear as tumor suppressor gene: MEG3 is the first lncRNA proposed to function as a tumor suppressor and also a top level regulatory RNA because of its ability stimulating both p53-dependent and p53-independent pathways [32,51]. Recurring chromosomal aberrations can influence the expression of many lncRNAs, such as disrupted in schizophrenia 1 and 2 (DISC1 and DISC2), which were involved in the development of various diseases [52,53]. For instance, a large number of SNPs in the DISC1 genomic sequence have been reported to be associated with schizophrenia spectrum disorder [54,55].

Emerging evidence has demonstrated that SNPs located in non-coding regions may be used as susceptibility factors to several diseases. Scott et al. reported that SNPs adjacent to the lncRNA ANRIL were associated with increased risks of type 2 diabetes [56]. The viewpoint was also confirmed by a separate study, which reported that distinct SNPs in the IncRNA ANRIL locus were associated with susceptibility to coronary artery disease and atherosclerosis [57]. Further characterization of the identified polymorphisms showed that SNPs can disrupt ANRIL splicing, leading to a circular transcript that is resistant to RNase digestion [35]. The circularized transcripts have effect on ANRIL normal function and influence INK4/ARF expression. Other evidence is from the recent study of leukemia and CRC which identified both germline and somatic mutations in lncRNA genes [58]. Recently, a novel IncRNA, named PRNCR1, has been discovered and was reported to be up-regulated in prostate cancer [19]. SNPs in the lncRNA PRNCR1 gene might influence the predicted secondary structure of PRNCR1 mRNA, alter the stability of the lncRNA PRNCR1 or the mRNA conformation, and result in the modification of its interacting partners [19]. Since the lncRNA PRNCR1 located in 8q24 which was a susceptibility locus to CRC [2-17,59], we hypothesized that SNPs in this region may have roles in the development of CRC. Our findings confirmed our hypothesis. We found that tag SNPs in the lncRNA PRNCR1 may be a protective factor against $\mathrm{CRC}$, suggesting that SNPs in lncRNA may be involved in the tumorigenesis of CRC. Although Chung and colleague's report suggested that the lncRNA PRNCR1 was associated with prostate carcinogenesis and may play a role through the regulation of androgen receptor (AR) transactivation activity [19], no report investigated the relationship between the region 2 of 8q24 and CRC risk. Moreover, there were reports suggested that AR also participated in the pathologic process of CRC through TGF $\beta$ pathway $[60,61]$. In this study, we found that the rs1456315 was also associated with clinical features of CRC, which was consistent with the report by Chung et al. [19].

Although we detected the association between SNPs in IncRNA and CRC, there were limitations needed to be mentioned in our study. One is that the follow-up information is blank, which limited our further analysis on the association between SNPs in lncRNA and CRC prognosis. Another is that the study subjects are all ethnic Han Chinese, and the sample size is moderate. Further large-scale studies in different populations, therefore, still need to be done.

\section{Conclusion}

In conclusion, we found that the variant genotypes of rs13252298 and rs1456315 may contribute to a decreased risk of CRC. Moreover, the rs7007694, rs16901946, and rs1456315 polymorphisms were associated with the tumor size and differentiated status of patients. Association studies with diverse populations and further functional analysis of the variants are needed to verify our findings. Once our understanding of lncRNAs language is clear, we will be able to classify diseases based on the identified mutations and their effect on lncRNA function. 


\section{Additional file}

Additional file 1: Table S1. Primer sequences and reaction conditions for genotyping the five SNPS.

\section{Competing interests}

None of the authors has any potential financial conflict of interest related to this manuscript.

\section{Authors' contributions}

$L L, G L B$ and ZL designed the study. LLJ, SRF, LYD, PXM, LZH, BP, ZXF and ZhDX performed genotyping. LLJ, SRF and GLB conducted statistical analysis. $\mathrm{LLJ}$ and $\mathrm{ZL}$ wrote the manuscript. All authors read and approved the final manuscript.

\section{Acknowledgements}

This work was supported by the special research foundation of doctoral priority to the development of field project (No.20110181130013), the National Natural Science Foundation of China (No. 81302149, 81202387), the Science \& Technology Pillar Program of Sichuan Province (14ZC1838, 2013JY0013), Distinguished Young Scientist of Sichuan University (No. 2013SCU04A38), and the Ph.D. Programs Foundation of Ministry of Education of China (No. 20130181120011).

\section{Author details}

${ }^{1}$ Laboratory of Molecular and Translational Medicine, West China Institute of Women and Children's Health; Key Laboratory of Obstetric \& Gynecologic and Pediatric Diseases and Birth Defects of Ministry of Education, West China Second University Hospital, Sichuan University, Chengdu, Sichuan 610041, P.R. China. 'Department of Forensic Biology, West China School of Preclinical and Forensic Medicine, Sichuan University, Chengdu, Sichuan 610041, P.R. China. ${ }^{3}$ Central Laboratory, Yunnan University of Chinese Traditional Medicine, Kunming 650500, Yunnan, P.R. China. ${ }^{4}$ Department of Forensic Pathology, College of Forensic Medicine, Henan University of Science and Technology, Luoyang, Henan 471003, P.R. China. ${ }^{5}$ Secondary Department of General Surgery, Luoyang Central Hospital Affiliated to Zhengzhou University, Luoyang, Henan 471003, P.R. China. ${ }^{6}$ Department of Forensic Medicine, Kunming Medical University, Kunming, Yunnan 650500, P.R. China.

Received: 12 October 2013 Accepted: 5 December 2013 Published: 13 December 2013

\section{References}

1. Mallardo M, Poltronieri P, D'Urso OF: Non-protein coding rna biomarkers and differential expression in cancers: a review. J Exp Clin Cancer Res 2008, 27:19.

2. Berndt SI, Potter JD, Hazra A, Yeager M, Thomas G, Makar KW, Welch R, Cross AJ, Huang WY, Schoen RE, Giovannucci E, Chan AT, Chanock SJ, Peters U, Hunter DJ, Hayes RB: Pooled analysis of genetic variation at chromosome 8q24 and colorectal neoplasia risk. Hum Mol Genet 2008, 17:2665-2672.

3. Cicek MS, Slager SL, Achenbach SJ, French AJ, Blair HE, Fink SR, Foster NR, Kabat BF, Halling KC, Cunningham JM, Cerhan JR, Jenkins RB, Boardman LA, Petersen GM, Sargent DJ, Alberts SR, Limburg PJ, Thibodeau SN: Functional and clinical significance of variants localized to $8 \mathrm{q} 24$ in colon cancer. Cancer Epidemiol Biomarkers Prev 2009, 18:2492-2500.

4. Ghoussaini M, Song HL, Koessler T, Al Olama AA, Kote-Jarai Z, Driver KE, Pooley KA, Ramus SJ, Kjaer SK, Hogdall E, DiCioccio RA, Whittemore AS, Gayther SA, Giles GG, Guy M, Edwards SM, Morrison J, Donovan JL, Hamdy FC, Dearnaley DP, Ardern-Jones AT, Hall AL, O'Brien LT, Gehr-Swain BN, Wilkinson RA, Brown PM, Hopper JL, Neal DE, Pharoah PDP, et al: Collaborators U P S: multiple loci with different cancer specificities within the 8q24 gene desert. J Natl Cancer / 2008, 100:962-966.

5. Gruber SB, Moreno V, Rozek LS, Rennerts HS, Lejbkowicz F, Bonner JD, Greenson JK, Giordano TJ, Fearson ER, Rennert G: Genetic variation in $8 q 24$ associated with risk of colorectal cancer. Cancer Biol Ther 2007, 6:1143-1147.

6. Kupfer SS, Torres JB, Hooker S, Anderson JR, Skol AD, Ellis NA, Kittles RA: Novel single nucleotide polymorphism associations with colorectal cancer on chromosome 8q24 in african and european americans. Carcinogenesis 2009, 30:1353-1357.

7. Li L, Plummer SJ, Thompson CL, Merkulova A, Acheson LS, Tucker TC, Casey G A common $8 \mathrm{q} 24$ variant and the risk of colon cancer: a population-based case-control study. Cancer Epidemiol Biomarkers Prev 2008, 17:339-342.

8. Matsuo K, Suzuki T, Ito H, Hosono S, Kawase T, Watanabe M, Shitara K Komori K, Kanemitsu Y, Hirai T, Yatabe Y, Tanaka H, Tajima K: Association between an $8 \mathrm{q} 24$ locus and the risk of colorectal cancer in japanese. BMC Cancer 2009, 9:379.

9. Middeldorp A, Jagmohan-Changur S, van Eijk R, Tops C, Devilee P, Vasen HFA Hes FJ, Houlston R, Tomlinson I, Houwing-Duistermaat JJ, Wijnen JT, Morreau $H$, van Wezel T: Enrichment of low penetrance susceptibility loci in a dutch familial colorectal cancer cohort. Cancer Epidemiol Biomarkers Prev 2009, 18:3062-3067.

10. Poynter JN, Figueiredo JC, Conti DV, Kennedy K, Gallinger S, Siegnumd KD, Casey G, Thibodeau SN, Jenkins MA, Hopper JL, Byrnes GB, Baron JA, Goode EL, Tiirikainen M, Lindor N, Grove J, Newcomb P, Jass J, Young J, Potter JD, Haile RW, Duggan DJ, Le Marchand L: Variants on 9p24 and 8q24 are associated with risk of colorectal cancer: results from the colon cancer family registry. Cancer Res 2007, 67:11128-11132.

11. Schafmayer C, Buch S, Volzke H, von Schonfels W, Egberts JH, Schniewind B, Brosch M, Ruether A, Franke A, Mathiak M, Sipos B, Henopp T, Catalcali J, Hellmig S, ElSharawy A, Katalinic A, Lerch MM, John U, Folsch UR, Fandrich F, Kalthoff H, Schreiber S, Krawczak M, Tepel J, Hampe J: Investigation of the colorectal cancer susceptibility region on chromosome $8 \mathrm{q} 24.21$ in a large german case-control sample. Int J Cancer 2009, 124:75-80.

12. Tenesa A, Farrington SM, Prendergast JG, Porteous ME, Walker M, Haq N, Barnetson RA, Theodoratou E, Cetnarskyj R, Cartwright N, Semple C, Clark AJ, Reid FJ, Smith LA, Kavoussanakis K, Koessler T, Pharoah PD, Buch S, Schafmayer C, Tepel J, Schreiber S, Volzke H, Schmidt CO, Hampe J, Chang-Claude J, Hoffmeister M, Brenner H, Wilkening S, Canzian F, Capella G, et al: Genome-wide association scan identifies a colorectal cancer susceptibility locus on $11 \mathrm{q} 23$ and replicates risk loci at $8 \mathrm{q} 24$ and 18q21. Nat Genet 2008, 40:631-637.

13. Tomlinson I, Webb E, Carvajal-Carmona L, Broderick P, Kemp Z, Spain S, Penegar S, Chandler I, Gorman M, Wood W, Barclay E, Lubbe S, Martin L, Sellick G, Jaeger E, Hubner R, Wild R, Rowan A, Fielding S, Howarth $K$, Silver A, Atkin W, Muir K, Logan R, Kerr D, Johnstone E, Sieber O, Gray R, Thomas H, Peto J, et al: A genome-wide association scan of tag snps identifies a susceptibility variant for colorectal cancer at $8 \mathrm{q} 24.21$. Nat Genet 2007, 39:984-988.

14. Tuupanen S, Niittymaki I, Nousiainen K, Vanharanta S, Mecklin JP, Nuorva K, Jarvinen $\mathrm{H}$, Hautaniemi S, Karhu A, Aaltonen LA: Allelic imbalance at rs6983267 suggests selection of the risk allele in somatic colorectal tumor evolution. Cancer Res 2008, 68:14-17.

15. Wokolorczyk D, Gliniewicz B, Sikorski A, Zlowocka E, Masojc B, Debniak T, Matyjasik J, Mierzejewski M, Medrek K, Oszutowska D, Suchy J, Gronwald J, Teodorczyk U, Huzarski T, Byrski T, Jakubowska A, Gorski B, Van De Wetering T, Walczak S, Narod SA, Lubinski J, Cybulski C: A range of cancers is associated with the rs6983267 marker on chromosome 8. Cancer Res 2008, 68:9982-9986.

16. Zanke BW, Greenwood CMT, Rangrej J, Kustra R, Tenesa A, Farrington SM, Prendergast J, Olschwang S, Chiang T, Crowdy E, Ferretti V, Laflamme $P$, Sundararajan S, Roumy S, Olivier J-F, Robidoux F, Sladek R, Montpetit A, Campbell P, Bezieau S, O'Shea AM, Zogopoulos G, Cotterchio M, Newcomb P, McLaughlin J, Younghusband B, Green R, Green J, Porteous MEM, Campbell $\mathrm{H}$, et al: Genome-wide association scan identifies a colorectal cancer susceptibility locus on chromosome 8q24. Nat Genet 2007, 39:989-994

17. Curtin K, Lin WY, George R, Katory M, Shorto J, Cannon-Albright LA, Bishop DT, Cox A, Camp NJ: Meta association of colorectal cancer confirms risk alleles at 8q24 and 18q21. Cancer Epidemiol Biomarkers Prev 2009, 18:616-621.

18. Pal P, Xi H, Guha S, Sun G, Helfand BT, Meeks JJ, Suarez BK, Catalona WJ, Deka R: Common variants in $8 \mathrm{q} 24$ are associated with risk for prostate cancer and tumor aggressiveness in men of european ancestry. Prostate 2009, 69:1548-1556.

19. Chung S, Nakagawa H, Uemura M, Piao L, Ashikawa K, Hosono N, Takata R, Akamatsu S, Kawaguchi T, Morizono T, Tsunoda T, Daigo Y, Matsuda K, Kamatani N, Nakamura Y, Kubo M: Association of a novel long non-coding rna in 8q24 with prostate cancer susceptibility. Cancer Sci 2011, 102:245-252. 
20. Ginger MR, Shore AN, Contreras A, Rijnkels M, Miller J, Gonzalez-Rimbau MF, Rosen JM: A noncoding rna is a potential marker of cell fate during mammary gland development. Proc Natl Acad Sci U S A 2006, 103:5781-5786

21. Mehler MF, Mattick JS: Noncoding rnas and rna editing in brain development, functional diversification, and neurological disease. Physiol Rev 2007, 87:799-823.

22. Dinger ME, Amaral PP, Mercer TR, Pang KC, Bruce SJ, Gardiner BB, AskarianAmiri ME, Ru K, Solda G, Simons C, Sunkin SM, Crowe ML, Grimmond SM, Perkins AC, Mattick JS: Long noncoding rnas in mouse embryonic stem cell pluripotency and differentiation. Genome Res 2008, 18:1433-1445.

23. Ravasi T, Suzuki H, Pang KC, Katayama S, Furuno M, Okunishi R, Fukuda S, Ru K, Frith MC, Gongora MM, Grimmond SM, Hume DA, Hayashizaki Y, Mattick JS: Experimental validation of the regulated expression of large numbers of non-coding rnas from the mouse genome. Genome Res 2006, 16:11-19.

24. Mercer TR, Dinger ME, Sunkin SM, Mehler MF, Mattick JS: Specific expression of long noncoding rnas in the mouse brain. Proc Natl Acad Sci U S A 2008, 105:716-721.

25. Ponting $\mathrm{CP}$, Oliver $\mathrm{PL}$, Reik W: Evolution and functions of long noncoding rnas. Cell 2009, 136:629-641.

26. Guttman M, Amit I, Garber M, French C, Lin MF, Feldser D, Huarte M, Zuk O, Carey BW, Cassady JP, Cabili MN, Jaenisch R, Mikkelsen TS, Jacks T, Hacohen N, Bernstein BE, Kellis M, Regev A, Rinn JL, Lander ES: Chromatin signature reveals over a thousand highly conserved large non-coding rnas in mammals. Nature 2009, 458:223-227.

27. Ponjavic J, Ponting CP, Lunter G: Functionality or transcriptional noise? Evidence for selection within long noncoding rnas. Genome Res 2007, 17:556-565.

28. Rearick D, Prakash A, McSweeny A, Shepard SS, Fedorova L, Fedorov A Critical association of ncrna with introns. Nucleic Acids Res 2011, 39:2357-2366

29. Carninci P, Kasukawa T, Katayama S, Gough J, Frith MC, Maeda N, Oyama R, Ravasi T, Lenhard B, Wells C, Kodzius R, Shimokawa K, Bajic VB, Brenner SE, Batalov S, Forrest AR, Zavolan M, Davis MJ, Wilming LG, Aidinis V, Allen JE, Ambesi-Impiombato A, Apweiler R, Aturaliya RN, Bailey TL, Bansal M, Baxter L, Beisel KW, Bersano $T$, Bono $H$, et al: The transcriptional landscape of the mammalian genome. Science 2005, 309:1559-1563.

30. Kapranov P, Drenkow J, Cheng J, Long J, Helt G, Dike S, Gingeras TR: Examples of the complex architecture of the human transcriptome revealed by race and high-density tiling arrays. Genome Res 2005, 15:987-997.

31. Li L, Feng T, Lian Y, Zhang G, Garen A, Song X: Role of human noncoding rnas in the control of tumorigenesis. Proc Natl Acad Sci U S A 2009, 106:12956-12961.

32. Zhang $X$, Rice $K$, Wang $Y$, Chen $W$, Zhong $Y$, Nakayama $Y$, Zhou $Y$, Klibanski A: Maternally expressed gene 3 (meg3) noncoding ribonucleic acid: Isoform structure, expression, and functions. Endocrinology 2010, 151:939-947.

33. Gupta RA, Shah N, Wang KC, Kim J, Horlings HM, Wong DJ, Tsai MC, Hung T, Argani P, Rinn JL, Wang Y, Brzoska P, Kong B, Li R, West RB, van de Vijver MJ, Sukumar S, Chang HY: Long non-coding rna hotair reprograms chromatin state to promote cancer metastasis. Nature 2010, 464:1071-1076.

34. Pibouin L, Villaudy J, Ferbus D, Muleris M, Prosperi MT, Remvikos $Y$, Goubin G: Cloning of the mrna of overexpression in colon carcinoma-1: a sequence overexpressed in a subset of colon carcinomas. Cancer Genet Cytogenet 2002, 133:55-60.

35. Burd CE, Jeck WR, Liu Y, Sanoff HK, Wang Z, Sharpless NE: Expression of linear and novel circular forms of an ink4/arf-associated non-coding rna correlates with atherosclerosis risk. PLoS Genet 2010, 6:e1001233.

36. Rinn JL, Kertesz M, Wang JK, Squazzo SL, Xu X, Brugmann SA, Goodnough LH, Helms JA, Farnham PJ, Segal E, Chang HY: Functional demarcation of active and silent chromatin domains in human hox loci by noncoding rnas. Cell 2007, 129:1311-1323.

37. Loewer S, Cabili MN, Guttman M, Loh YH, Thomas K, Park IH, Garber M, Curran M, Onder T, Agarwal S, Manos PD, Datta S, Lander ES, Schlaeger TM, Daley GQ, Rinn JL: Large intergenic non-coding rna-ror modulates reprogramming of human induced pluripotent stem cells. Nat Genet 2010, 42:1113-1117.

38. Castle JC, Armour CD, Lower M, Haynor D, Biery M, Bouzek H, Chen RH, Jackson S, Johnson JM, Rohl CA, Raymond CK: Digital genome-wide ncrna expression, including snornas, across 11 human tissues using polyaneutral amplification. PLoS One 2010, 5:e11779.

39. Wu SC, Kallin EM, Zhang Y: Role of h3k27 methylation in the regulation of Incrna expression. Cell Res 2010, 20:1109-1116.

40. Taft RJ, Pang KC, Mercer TR, Dinger M, Mattick JS: Non-coding rnas: regulators of disease. J Pathol 2010, 220:126-139.

41. Maruyama R, Shipitsin M, Choudhury S, Wu ZH, Protopopov A, Yao J, Lo PK, Bessarabova M, Ishkin A, Nikolsky Y, Liu XS, Sukumar S, Polyak K: Altered antisense-to-sense transcript ratios in breast cancer. Proc Natl Acad Sci U S A 2012, 109:2820-2824.

42. Silva JM, Perez DS, Pritchett JR, Hailing ML, Tang H, Smith DI: Identification of long stress-induced non-coding transcripts that have altered expression in cancer. Genomics 2010, 95:355-362.

43. Perez DS, Hoage TR, Pritchett JR, Ducharme-Smith AL, Halling ML, Ganapathiraju SC, Streng PS, Smith DI: Long, abundantly expressed non-coding transcripts are altered in cancer. Hum Mol Genet 2008, 17:642-655.

44. Guffanti A, lacono M, Pelucchi P, Kim N, Solda G, Croft LJ, Taft RJ, Rizzi E, Askarian-Amiri M, Bonnal RJ, Callari M, Mignone F, Pesole G, Bertalot G, Bernardi LR, Albertini A, Lee C, Mattick JS, Zucchi I, De Bellis G: A transcriptional sketch of a primary human breast cancer by 454 deep sequencing. BMC Genomics 2009, 10:163.

45. Ji P, Diederichs S, Wang W, Boing S, Metzger R, Schneider PM, Tidow N, Brandt B, Buerger H, Bulk E, Thomas M, Berdel WE, Serve H, Muller-Tidow C Malat-1, a novel noncoding rna, and thymosin beta4 predict metastasis and survival in early-stage non-small cell lung cancer. Oncogene 2003, 22:8031-8041

46. Barsyte-Lovejoy D, Lau SK, Boutros PC, Khosravi F, Jurisica I, Andrulis IL, Tsao MS, Penn LZ: The c-myc oncogene directly induces the h19 noncoding rna by allele-specific binding to potentiate tumorigenesis. Cancer Res 2006, 66:5330-5337

47. Yamada K, Kano J, Tsunoda H, Yoshikawa H, Okubo C, Ishiyama T, Noguchi M: Phenotypic characterization of endometrial stromal sarcoma of the uterus. Cancer Sci 2006, 97:106-112.

48. Lin R, Maeda S, Liu C, Karin M, Edgington TS: A large noncoding rna is a marker for murine hepatocellular carcinomas and a spectrum of human carcinomas. Oncogene 2007, 26:851-858.

49. Luo JH, Ren B, Keryanov S, Tseng GC, Rao UN, Monga SP, Strom S, Demetris AJ, Nalesnik M, Yu YP, Ranganathan S, Michalopoulos GK: Transcriptomic and genomic analysis of human hepatocellular carcinomas and hepatoblastomas. Hepatology 2006, 44:1012-1024.

50. Colnot S, Niwa-Kawakita M, Hamard G, Godard C, Le Plenier S, Houbron C, Romagnolo B, Berrebi D, Giovannini M, Perret C: Colorectal cancers in a new mouse model of familial adenomatous polyposis: influence of genetic and environmental modifiers. Lab Invest 2004, 84:1619-1630.

51. Zhou Y, Zhong Y, Wang Y, Zhang X, Batista DL, Gejman R, Ansell PJ, Zhao J, Weng C, Klibanski A: Activation of p53 by meg3 non-coding rna. J Biol Chem 2007, 282:24731-24742.

52. Calin GA, Liu CG, Ferracin M, Hyslop T, Spizzo R, Sevignani C, Fabbri M, Cimmino A, Lee EJ, Wojcik SE, Shimizu M, Tili E, Rossi S, Taccioli C, Pichiorri F, Liu X, Zupo S, Herlea V, Gramantieri L, Lanza G, Alder H, Rassenti L, Volinia S, Schmittgen TD, Kipps TJ, Negrini M, Croce CM: Ultraconserved regions encoding ncrnas are altered in human leukemias and carcinomas. Cancer Cell 2007, 12:215-229.

53. Millar JK, Wilson-Annan JC, Anderson S, Christie S, Taylor MS, Semple CA, Devon RS, St Clair DM, Muir WJ, Blackwood DH, Porteous DJ: Disruption of two novel genes by a translocation co-segregating with schizophrenia. Hum Mol Genet 2000, 9:1415-1423.

54. Devon RS, Anderson S, Teague PW, Burgess P, Kipari TMJ, Semple CAM, Millar JK, Muir WJ, Murray V, Pelosi AJ, Blackwood DHR, Porteous DJ: Identification of polymorphisms within disrupted in schizophrenia 1 and disrupted in schizophrenia 2, and an investigation of their association with schizophrenia and bipolar affective disorder. Psychiatr Genet 2001, 11:71-78.

55. Ekelund J, Hennah W, Hiekkalinna T, Parker A, Meyer J, Lonnqvist J, Peltonen L: Replication of 1q42 linkage in finnish schizophrenia pedigrees. Mol Psychiatry 2004, 9:1037-1041

56. Scott LJ, Mohlke KL, Bonnycastle LL, Willer CJ, Li Y, Duren WL, Erdos MR, Stringham HM, Chines PS, Jackson AU, Prokunina-Olsson L, Ding CJ, Swift AJ, Narisu N, Hu T, Pruim R, Xiao R, Li XY, Conneely KN, Riebow NL, Sprau AG, Tong M, White PP, Hetrick KN, Barnhart MW, Bark CW, Goldstein JL, Watkins L, 
Xiang F, Saramies J, et al: A genome-wide association study of type 2 diabetes in finns detects multiple susceptibility variants. Science 2007, 316:1341-1345.

57. Broadbent HM, Peden JF, Lorkowski S, Goel A, Ongen H, Green F, Clarke R, Collins R, Franzosi MG, Tognoni G, Seedorf U, Rust S, Eriksson P, Hamsten A, Farrall $\mathrm{M}$, Watkins $\mathrm{H}$, Consortium P: Susceptibility to coronary artery disease and diabetes is encoded by distinct, tightly linked snps in the anril locus on chromosome 9p. Hum Mol Genet 2008, 17:806-814.

58. Wojcik SE, Rossi S, Shimizu M, Nicoloso MS, Cimmino A, Alder H, Herlea V, Rassenti LZ, Rai KR, Kipps TJ, Keating MJ, Croce CM, Calin GA: Noncodingrna sequence variations in human chronic lymphocytic leukemia and colorectal cancer. Carcinogenesis 2010, 31:208-215.

59. Haiman CA, Le Marchand L, Yamamato J, Stram DO, Sheng X, Kolonel LN, Wu AH, Reich D, Henderson BE: A common genetic risk factor for colorectal and prostate cancer. Nat Genet 2007, 39:954-956.

60. Ferro P, Catalano MG, Dell'Eva R, Fortunati N, Pfeffer U: The androgen receptor cag repeat: a modifier of carcinogenesis? Mol Cell Endocrinol 2002, 193:109-120

61. Mariani M, Zannoni GF, Sioletic S, Sieber S, Martino C, Martinelli E, Coco C, Scambia G, Shahabi S, Ferlini C: Gender influences the class iii and v beta-tubulin ability to predict poor outcome in colorectal cancer. Clin Cancer Res 2012, 18:2964-2975.

doi:10.1186/1756-9966-32-104

Cite this article as: $L i$ et al:: Association between polymorphisms in long non-coding RNA PRNCR1 in 8q24 and risk of colorectal cancer. Journal of Experimental \& Clinical Cancer Research 2013 32:104.

\section{Submit your next manuscript to BioMed Central and take full advantage of:}

- Convenient online submission

- Thorough peer review

- No space constraints or color figure charges

- Immediate publication on acceptance

- Inclusion in PubMed, CAS, Scopus and Google Scholar

- Research which is freely available for redistribution 